\title{
PENGARUH STERILISASI DAN PENYIMPANAN SUHU RENDAH TERHADAP MUTU PINDANG BANDENG PRESTO
}

\author{
Mohammad Saleh", Dwi Artini Iswahyuningsih"*), Ninoek Indriati*) \\ dan Endang Sri Heruwati*)
}

\begin{abstract}
ABSTRAK
Penelitian mengenai sterilisasi dan penyimpanan bandeng presto pada suhu rendah untuk mempertahankan mutu produk telah dilakukan. Dalam penelitian ini, ikan dipindang pada $121^{\prime} \mathrm{C}$ selama 45 menit. diikuti dengan pengemasan hampa udara dalam kantong HDPE, kemudian dibagi menjadi empat kelompok. Kelompok pertama dan ke dua langsung disimpan masing. masing pada suhu kamar $\left(26-32^{\prime \prime} \mathrm{C}\right)$ dan suhu rendah $\left(5.7^{\circ} \mathrm{C}\right)$, sedangkan dua kelompok lain dimasak kembali (sterilisasi) pada $118^{\circ} \mathrm{C}$ selama 15 menit, kemudian disimpan pada dua suhu seperti halnya dua kelompok yang lain. Selama penyimpanan bandeng presto diamati mutu organoleptik, aktivitas air, jumlah bakteri total dan bakteri gram positif, serta jumlah basa menguap (TVB) dan asam tiobarbiturat (TBA) setiap lima hari selama empat minggu, kecuali bandeng presto yang tidak disterilkan yang disimpan pada suhu kamar diamati setiap hari selama satu minggu. Hasil percobaan menunjukkan bahwa berdasarkan jumlah bakteri dan basa menguap, produk yang disterilkan dan disimpan pada suhu rendah adalah yang terbaik di antara tiga perlakuan. diikuti dengan produk yang disterilkan dan disimpan pada suhu kamar, meskipun secara organoleptis ketiga perlakunn tidak berbeda satu sama lain, dan masih diterima panelis hingga empat minggu penyimpanan. Sebaliknya pada produk yang tidak disterilkan dan tidak disimpan pada suhu rendah, daya awetnya kurang dari satu minggu. Dari hasil ini dapat disimpulkan bahwa sterilisasi ulang tidak seefektif penyimpanan suhu rendah dalam mempertahankan mutu bandeng presto, namun demikian teknologi sterilisasi, apalagi bila dikombinasikan dengan penyimpanan pada suhu rendah, sangat membantu mempertahankan mutu bandeng presto.
\end{abstract}

ABSTRACT: The effect of sterilization and low temperature storage on the quality of pressure-cooked milkfish. By: Mohammad Saleh, Dwi Artini Iswahyuningsih, Ninoek Indriati, and Endang Sri Heruwati.

The importance of product sterilization and low temperature storage in maintaining the quality of pressure-cooked milkfish was investigated. In this experiment, spiced gutted milkfish, weighing of $250-300 \mathrm{~g}$ each, were pressure-cooked at $12 \mathrm{I}^{\prime \prime C}$ for $45 \mathrm{~min}$, cooled for about $1 \mathrm{~h}$, and vacuum packed in HDPE pouches. They were then divided into four lots. The first lot was stored under ambient temperature $\left(26-32^{\circ} \mathrm{C}\right)$. Another was stored at chill temperature $\left(5-7^{\circ} \mathrm{C}\right)$. The third and fourth were sterilized at $118^{\circ} \mathrm{C}$ for $15 \mathrm{~min}$. After colling, the two sterilized lots were stored at room and chill temperatures. All lots, except those unsterilized and kept at ambient temperature, were examined for their organoleptic quality, water activity, total and gram positive bacteria, total volatile bases (TVB) and thiobarbituric acid (TBA) content every five days during four-week storage, while unsterilized was assessed for the same quality paramaters everyday during the week. It was shown that based on the total bacterial count and TVB content, the sterilized, low temperature stored product was the best among the three treated products, followed by sterilized, room temperature stored product, though, organoleptically, they were not different to each other, and were still acceptable till four-week storage. On the contrary, the shelflife of the control was less than a week. It could be concluded that eventhough the effect of re-sterilization was not as good as low temperature storage in prolonging the product's shelflife, however, proper sterilization preferably in combination with low temperature storage was the best way to maintain the quality of pressure cooked milkfish.

KEYWORDS: pressure-cooking, low temperature storage, milkfish.

† Peneliti pada Balai Penelitian Perikanan Laut

*) Mahasiswa S1 Fak. Perikanan, IPB 


\section{PENDAHULUAN}

Pemindangan ikan mempunyai prospek yang baik untuk dikembangkan, terutama dalam rangka peningkatan konsumsi ikan dan sebagai alternatif pengolahan yang mudah dan murah untuk dikembangkan di pusat-pusat produksi ikan yang pada umumnya masih menghadapi kendala keterbatasan sarana dan prasarana. Namun demikian, pada kondisi penyimpanan biasa (suhu kamar), pindang ikan hanya dapat disimpan selama 2-6 hari (Mulyanah et al., 1986; Suparno \& Murtini, 1981). Kondisi ini tentu tidak memungkinkan pengiriman ikan pindang ke tempat yang jauh, misalnya dari bagian timur Indonesia sebagai pusat produsen ikan, ke Jawa sebagai pusat konsumen ikan, yang memerlukan waktu lebih dari satu minggu. Untuk memecahkan permasalahan tersebut, berbagai penelitian tentang perbaikan mutu dan perpanjangan daya awet ikan pindang telah dilakukan, baik yang berupa pengawetan bahan baku ikan sebelum dipindang, perbaikan teknik pemindangan (suhu dan waktu pemindangan, kadar garam, penambahan bumbu, dll.), pengunaan zat-zat pengawet, perbaikan pengemasan, aplikasi teknik radiasi, maupun teknik penyimpanan produk (Heruwati, 1985).

Pengembangan produk pindang yang dinilai cukup berhasil adalah 'pindang presto'. Produk ini diolah dengan menggunakan suhu tinggi sehingga tulang ikan menjadi lunak. Selain itu, penampilan produk lebih bersih dan baik, dan dengan kemasan yang menarik mampu menjaring konsumen golongan menengah ke atas. Produk ini telah tersedia di banyak pasar swa. layan di Indonesia. Akan tetapi, tanpa bantuan pengemasan hampa udara dan atau penyimpanan pada suhu rendah, pindang presto pun tidak akan tahan lebih dari satu minggu.

Bentuk pengembangan lain yang dewasa ini masih pada tahap uji coba adalah pengolahan ikan dalam kemasan plastik tahan panas (retortable pouch). Gagasan pengolahan produk ini diawali dengan upaya mengatasi kelangkaan kemasan kaleng dengan kemasan plastik. Teknologi ini menggunakan kemasan kantong polietilen berkerapatan tinggi (HDPE) yang tahan panas dengan ketebalan 100 mikron, dan prosesnya terdiri atas pemanasan pendahuluan selama 30 menit pada $121^{\circ} \mathrm{C}$, diteruskan dengan penambahan media dan penutupan hampa udara dilanjut- kan dengan sterilisasi pada $118^{\circ} \mathrm{C}$ selama 60 menit, diikuti dengan proses pendinginan (Saleh et. al, 1992). Dengan cara ini, lemuru pindang dapat disimpan pada suhu kamar hingga enam minggu tanpa mengalami perubahan yang berarti (Saleh et al., 1993). Dari hasil uji konsumen yang melibatkan 90 responden di Bandung, Cirebon, dan DKI Jaya, produk yang memerlukan biaya produksi Rp 203,32 per 180 gram ini ternyata dapat diterima oleh $50 \%$ responden (Noor et al., 1994). Salah satu kelemahan dari teknologi ini terletak pada tahap sterilisasi yang memerlukan peralatan yang dirancang khusus.

Di lain fihak, pengalaman selama ini menunjukkan bahwa penyimpanan pada suhu rendah cukup handal dalam mempertahankan daya awet ikan pindang. Ini dibuktikan oleh Suparno (1990) dengan ikan sprat yang mampu bertahan hingga delapan minggu pada suhu $5^{\circ} \mathrm{C}$ bila dikemas hampa udara atau atmosfir yang dimodifikasi $\left(60 \% \mathrm{CO}_{2}, 40 \% \mathrm{~N}_{2}\right.$,), atau empat minggu bila menggunakan pengemasan biasa. Walaupun penelitian ini lebih ditekankan pada metode pengemasan, namun secara umum dapat menunjukkan efek positif penyimpanan suhu rendah dibandingkan dengan penyimpanan pada suhu kamar yang biasanya hanya dapat tahan selama satu minggu (Heruwati, 1985).

Untuk mengetahui apakah sebenarnya teknologi penyimpanan pada suhu rendah saja tanpa sterilisasi telah cukup untuk mempertahankan daya awet ataukah perlu dilakukan kombinasi dari keduanya, dilakukan penelitian tentang pengaruh sterilisasi dan atau penyimpanan pada suhu rendah terhadap pindang bandeng presto yang dikemas hampa udara.

\section{BAHAN DAN METODE}

Penelitian yang dilakukan di laboratorium Inlitkanlut Slipi ini menggunakan ikan bandeng (Chanos chanos) yang diperoleh dari tambak di Pasir Kuda, Tangerang. Ukuran ikan yang digunakan adalah panjang $25.27 \mathrm{~cm}$ dengan bobot 250-300 g/ekor. Setelah penyiangan dan pencucian, ikan diberi bumbu (menggunakan resep dari pengolah pindang bandeng 'presto' di Semarang) yang terdiri atas bawang putih $(0,11 \%)$, ketumbar $(0,08 \%)$, kunyit $(4 \%)$, jintan $(0,08 \%)$, dan garam dapur $(8 \%)$, kemudian dilanjutkan dengan pemanasan pendahuluan pada 121 "C selama 45 menit. Setelah didinginkan 
selama satu jam, ikan pindang dikemas dalam kantong HDPE berukuran $30 \times 13 \mathrm{~cm}$ dengan ketebalan 100 mikron, diteruskan dengan penutupan hingga mencapai tingkat hampa udara $70 \%$. Pendinginan dan pengemasan dalam kantong HDPE dilakukan pada ruang laminar (laminar flow chamber) untuk mengurangi terjadinya kontaminasi mikroorganisme.

Ikan pindang kemudian dibagi menjadi empat kelompok. Kelompok 1 dan 2 langsung disimpan tanpa sterilisasi, yaitu kelompok $1(\mathrm{~K})$ pada suhu kamar $\left(26-32^{\circ} \mathrm{C}\right)$ dan kelompok 2 (D) pada suhu rendah (5.7 "C). Adapun kelompok 3 dan 4 diteruskan dengan sterilisasi pada $118^{\circ} \mathrm{C}$ selama 15 menit. Sterilisasi dilakukan dalam otoklaf yang dimodifikasi dengan cara menghubungkannya dengan kompresor udara. Setelah proses sterilisasi selesai, ke dalam otoklaf dialirkan udara bertekanan $3 \mathrm{~atm}$. yang berasal dari kompresor. Bersamaan dengan itu tekanan uap air dalam otoklaf diturunkan hingga mencapai 1 atm. Selanjutnya ke dalam otoklaf dialirkan air pendingin. Pendinginan ini dilakukan selama sekitar 30 menit sehingga suhu menjadi $30^{\circ} \mathrm{C}$. Hal ini dimaksudkan untuk mencegah pecahnya kantong plastik karena penurunan tekanan secara mendadak. Kelompok 3 (SK) dipisahkan untuk disimpan pada suhu kamar, sedangkan kelompok 4 (SD) disimpan pada suhu rendah.

Selama penyimpanan dilakukan pengamatan terhadap mutu organoleptik yang meliputi rupa, bau, warna, rasa, dan tekstur; serta mutu obyektif yang terdiri atas aktivitas air, jumlah basa menguap (TVB), jumlah asam tiobarbiturat (TBA), jumlah bakteri total dan jumlah bakteri gram positif. Kelompok perlakuan (kelompok 2, 3, dan 4) disimpan selama 30 hari dengan pengamatan setiap lima hari; sedangkan untuk kelompok 1 (kontrol), pengamatan dilakukan setiap hari selama tujuh hari.

Penelitian dilakukan menggunakan rancang. an acak lengkap dengan empat ulangan, dengan penilaian mutu organoleptik dilakukan oleh enam panelis.

\section{HASIL DAN PEMBAHASAN}

\section{Kelompok Kontrol}

Hasil pengamatan mutu organoleptik kelompok kontrol adalah seperti pada Gambar 1 dan 2. Terlihat pada Gambar 1 bahwa kecuali rupa, nilai organoleptik telah melewati ambang batas kesegaran (skor 5) pada hari ke enam.

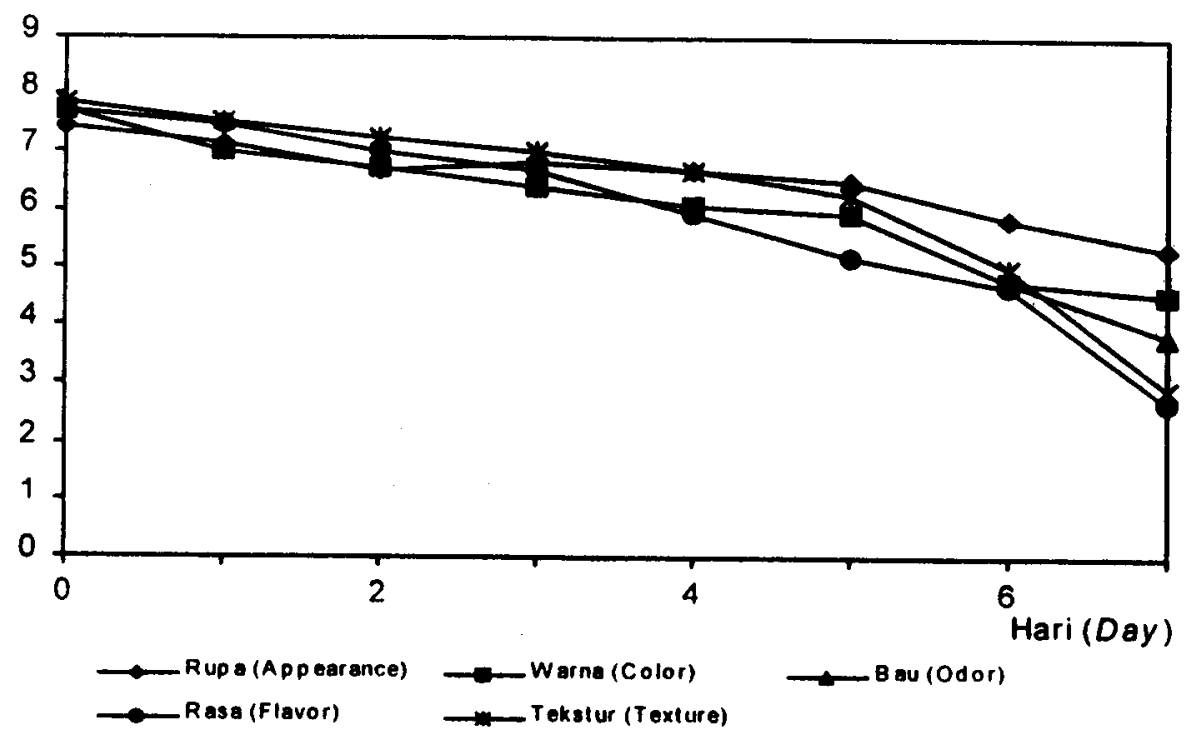

Gambar 1. Perubahan mutu organoleptik (skor) pindang presto tanpa sterilisasi yang disimpan pada suhu kamar.

Figure 1. Changes of organoleptic quality (scores) of unsterilized pressure-cooked pindang during storage at room temperature. 


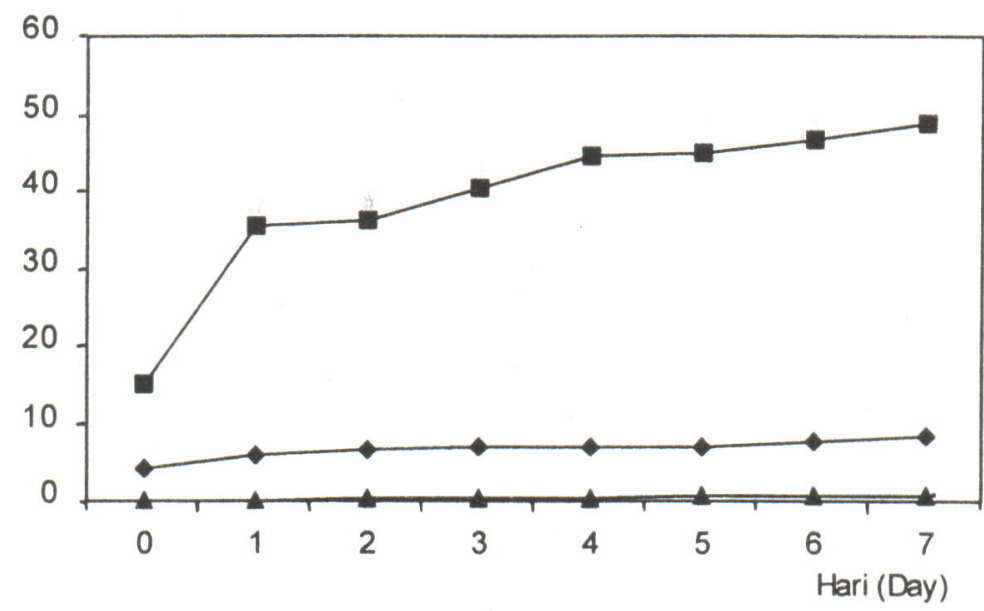

TPC $(\log )$ $\operatorname{TVB}(\mathrm{mgN} \%) \longrightarrow$ TBA $(\mathrm{um} \mathrm{MA} / \mathrm{g})$

Gambar 2. TPC, TVB, dan TBA pindang presto yang tidak disterilisasi dan disimpan pada suhu kamar. Figure 2. TPC, TVB, and TBA of unsterilized pressure-cooked pindang stored at room temperature.

Pada Gambar 2 tampak bahwa jumlah basa menguap TVB telah melonjak dari $15,16 \mathrm{mgN} \%$ menjadi $35,47 \mathrm{mgN} \%(234 \%)$ pada hari berikutnya, tetapi kemudian laju peningkatan mulai lambat dan mencapai $48,97 \mathrm{mgN} \%(323 \%)$ pada hari ke tujuh. Kadar asam tiobarbiturat, yang merupakan indikator'ketengikan, meningkat secara linier dari $0,046 \mu \mathrm{mol}$ malonaldehid $/ \mathrm{kg}$ menjadi $0,639 \mu \mathrm{mol}$ malonaldehid $/ \mathrm{kg}(1389 \%)$ pada akhir penyimpanan. Peningkatan jumlah bakteri terlihat menyerupai pola perubahan TVB, yakni meningkat dengan cepat pada hari pertama, yaitu dari $1,2 \times 10^{4}$ menjadi $8,5 \times 10^{5}$, kemudian terus meningkat tetapi dengan kecepatan yang lebih rendah, hingga mencapai $2,8 \times 10^{8}$ pada hari ke tujuh. Dari jumlah tersebut, terdapat bakteri gram positif sebanyak $1,4 \times 10^{1}(26,4 \%$ dari total bakteri) pada awal percobaan, yang kemudian menjadi $5,3 \times 10^{4}$ (55,9\% dari total bakteri) pada akhir penyimpanan.

Pada kelompok kontrol ini, relatif tidak terjadi perubahan aktivitas air, yang berkisar antara 0,962 hingga 0,965 .

\section{Kelompok Perlakuan}

Mutu organoleptik (bau, rasa, tekstur, dan rupa) dan aktivitas air selama penyimpanan menunjukkan tidak terjadinya perubahan nyata antar perlakuan (Tabel 1), kecuali untuk aktivitas air dari produk yang disterilisasi dan disimpan pada suhu rendah. Ini menunjukkan bahwa aktivitas air produk yang disimpan pada suhu kamar, baik yang disterilisasi maupun yang tidak, lebih berfluktuasi dibandingkan dengan yang disimpan pada suhu rendah. Hal ini terjadi karena ruang penyimpanan pada suhu kamar tidak terkontrol suhu maupun kelembabannya. Namun demikian secara keseluruhan, pada hari ke 30 nilai organoleptik ketiga perlakuan masih di atas ambang penerimaan panelis (skor 5).

Dalam hal jumlah bakteri, perlakuan tanpa sterilisasi, walaupun disimpan pada suhu rendah, mempunyai laju peningkatan yang paling cepat (hingga $10^{6}$ pada hari ke-10) dibandingkan dengan perlakuan yang lain, yang hanya mencapai $10^{2} \cdot 10^{3}$ pada hari yang sama. Perbedaan suhu penyimpanan untuk perlakuan sterilisasi ternyata juga memberikan perbedaan laju peningkatan bakteri (Gambar 3). Dari jumlah tersebut, proporsi bakteri gram positif yang semula hanya $48,4 \%$ meningkat menjadi $80,9 \%$ pada hari ke-30 untuk perlakuan tanpa sterilisasi, sedangkan untuk perlakuan sterilisasi, baik yang disimpan pada suhu rendah maupun suhu kamar, $100 \%$ bakteri pada awal dan akhir penyimpanan adalah gram positif. Perlakuan sterilisasi memang baik untuk mencegah berkembangnya Staphylococcus aureus, bakteri yang sering menjadi masalah pada produk-produk yang banyak mengalami kontak dengan pengolah, apalagi bila cara penanganannya kurang higienis. Namun demikian, mengingat pada 
penelitian ini seluruh bakteri yang mampu bertahan pada produk yang disterilisasi adalah gram positif, kemungkinan adanya Clostridium botulinum dapat terjadi.

Tabel 1. Nilai $A_{w}$ dan skor organoleptik pindang presto selama penyimpanan

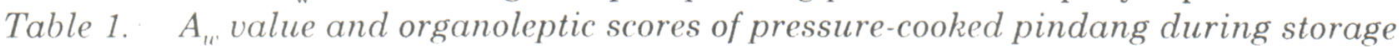

\begin{tabular}{|c|c|c|}
\hline $\begin{array}{c}\text { Parameter/perlakuan } \\
\text { (Treatments) }\end{array}$ & $\begin{array}{c}\text { Awal } \\
\text { penyimpanan } \\
\text { (Initial storage) }\end{array}$ & $\begin{array}{c}\text { Akhir } \\
\text { penyimpanan } \\
\text { (Final storage) }\end{array}$ \\
\hline \multicolumn{3}{|l|}{ Bau (Odor) } \\
\hline $\mathrm{D}$ & $7.3 \pm 1.1$ & $5.6 \pm 0.5^{\mathrm{a}}$ \\
\hline $\mathrm{SD}$ & $7.3 \pm 1.1$ & $5.9 \pm 0.6^{\mathrm{a}}$ \\
\hline SK & $7.3 \pm 1.1$ & $6.0 \pm 0.6^{\mathrm{a}}$ \\
\hline \multicolumn{3}{|l|}{ Rasa (Flavor) } \\
\hline $\mathrm{D}$ & $7.3 \pm 0.7$ & $5.9 \pm 0.6^{i}$ \\
\hline $\mathrm{SD}$ & $7.3 \pm 0.7$ & $6.2 \pm 0.5^{\mathrm{a}}$ \\
\hline SK & $7.3 \pm 0.7$ & $5.7 \pm 0.5^{\mathrm{a}}$ \\
\hline \multicolumn{3}{|l|}{ Tekstur (Texture) } \\
\hline $\mathrm{D}$ & $7.6 \pm 1.3$ & $6.0 \pm 0.8^{a}$ \\
\hline $\mathrm{SD}$ & $7.6 \pm 1.3$ & $6.3 \pm 0.7^{\mathrm{a}}$ \\
\hline SK & $7.6 \pm 1.3$ & $6.2 \pm 0.3^{\mathrm{a}}$ \\
\hline \multicolumn{3}{|l|}{ Rupa (Appearance) } \\
\hline $\mathrm{D}$ & $7.5 \pm 0.0$ & $6.1 \pm 0.42^{a}$ \\
\hline $\mathrm{SD}$ & $7.5 \pm 0.0$ & $5.9 \pm 0.45^{a}$ \\
\hline $\mathrm{SK}$ & $7.5 \pm 0.0$ & $5.7 \pm 0.52^{a}$ \\
\hline \multicolumn{3}{|l|}{$\mathrm{A}_{\mathrm{w}}$} \\
\hline D & $0.964 \pm 0.002$ & $0.962 \pm 0.003^{a}$ \\
\hline $\mathrm{SD}$ & $0.977 \pm 0.002$ & $0.965 \pm \cdot 0.001^{\text {a }}$ \\
\hline SK & $0.977 \pm 0.002$ & $0.960 \pm 0.009^{a}$ \\
\hline
\end{tabular}

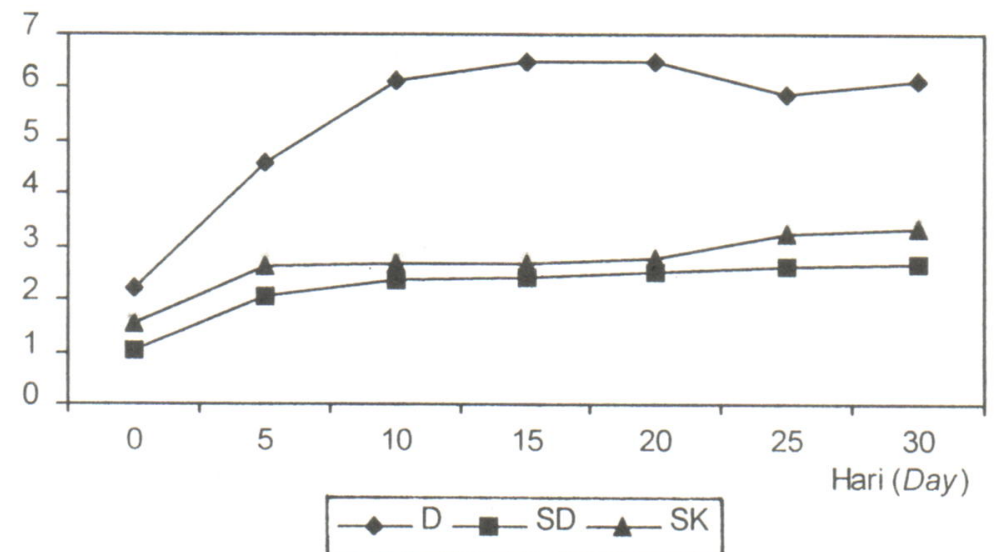

Gambar 3. Jumlah bakteri (cfu/g) pindang presto selama penyimpanan.

Figure 3. Total bacterial count $(c \mathrm{fu} / \mathrm{g})$ of pressure cooked pindang during storage. 
Perubahan jumlah basa menguap (TVB) sedikit berbeda dengan pola perubahan jumlah bakteri (Gambar 4). Hingga hari ke-15, semua perlakuan tidak menunjukkan perbedaan, yaitu berkisar antara 67,24 hingga $70,80 \mathrm{mgN} \%$. Tetapi setelah itu, perlakuan tanpa sterilisasi yang disimpan pada suhu rendah mempunyai laju pembentukan TVB yang nyata tercepat, mencapai $95,07 \mathrm{mgN} \%$, diikuti dengan perlakuan sterilisasi dengan penyimpanan pada suhu kamar $(83,15$ $\mathrm{mgN} \%)$, sedangkan perlakuan sterilisasi dengan penyimpanan pada suhu rendah mempunyai laju yang paling lambat, yakni mencapai $76,31 \mathrm{mgN} \%$ pada hari ke-30.

Asam tiobarbiturat (TBA) meningkat dengan sangat lambat dari sekitar $0,05 \mu \mathrm{mol}$ malonaldehid/kg menjadi $0,51-0,81 \mu \mathrm{mol} / \mathrm{kg}$ pada hari ke25. Namun setelah itu selain terjadi peningkatan laju pembentukan TBA juga terjadi perbedaan pola perubahan jumlah TBA antar perlakuan. Pada Gambar 5 terlihat bahwa selama penyimpanan, perlakuan tanpa sterilisasi yang disimpan pada suhu rendah justru tidak banyak mengalami peningkatan, yaitu mencapai $1,17 \mu \mathrm{mol}$ malonaldehid/kg pada hari ke-30. Adapun perlakuan dengan sterilisasi, baik yang disimpan pada suhu kamar maupun suhu rendah, justru mempunyai laju peningkatan TBA yang lebih cepat yakni masing-masing 1,88 dan $2,28 \mu \mathrm{mol}$ malonaldehid/kg ikan. Hal ini kemungkinan disebabkan oleh perubahan porositas atau terjadinya kerusakan (deformasi) kantong akibat suhu tinggi (yang berarti juga tekanan tinggi) yang diberikan selama proses sterilisasi, sehingga tingkat hampa udara berkurang, dan memberi peluang terjadinya proses oksidasi selama produk disimpan.

Dari hasil percobaan di atas dikaitkan dengan hasil-hasil penelitian sebelumnya menunjukkan bahwa kemasan hampa udara saja tanpa penyimpanan suhu rendah tidak mampu mempertahankan daya awet ikan pindang hingga satu minggu. Sebaliknya, penyimpanan suhu rendah tanpa sterilisasi, dengan atau tanpa kemasan hampa udara, telah dapat memperpanjang masa simpan hingga 4-8 minggu, tergantung jenis dan ukuran ikan serta kadar garam dan lamanya perebusan. Perlakuan sterilisasi, baik pada penyimpanan suhu kamar maupun suhu rendah, tidak menunjukkan perbedaan dengan perlakuan tanpa sterilisasi yang disimpan pada suhu rendah, khususnya bila dilihat dari mutu organoleptiknya. Dari kenyataan tersebut tampaknya teknologi sterilisasi belum cukup efektif dalam memperpanjang daya awet produk, yang kemungkinan disebabkan oleh suhu dan waktu sterilisasi yang kurang atau karena terjadinya deformasi kantong plastik.
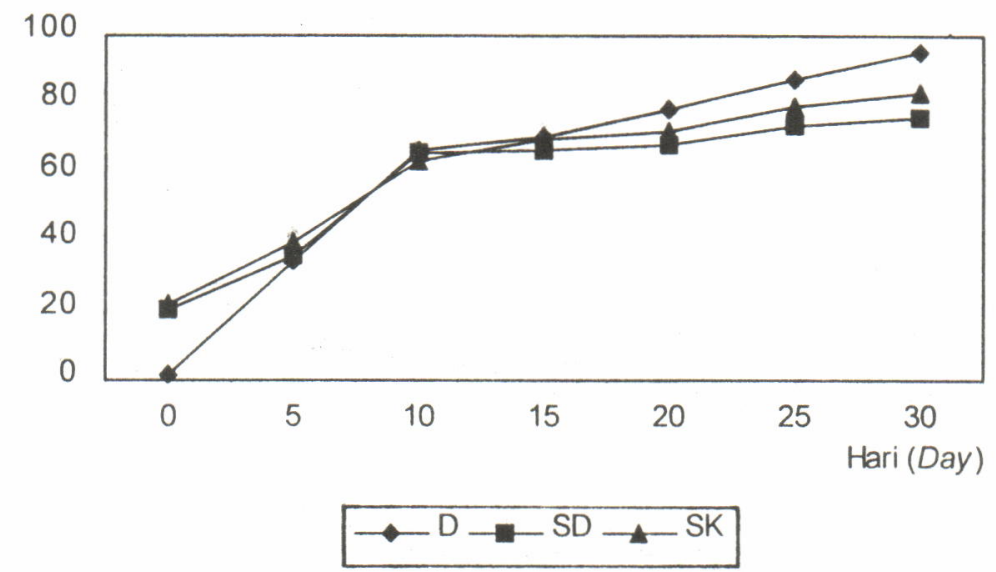

D: Tanpa sterilisasi, penyimpanan suhu rendah (unsterilized, low temperature storage) SD: Dengan sterilisasi, penyimpanan suhu rendah (sterilized, low temperature storage) SK: Dengan sterilisasi, penyimpanan suhu kamar (sterilized, room temperature storage)

Gambar 4. TVB (mgN\%) pindang presto selama penyimpanan.

Figure 4. TVB $(\mathrm{mgN} \%)$ of pressure-cooked pindang during storage. 
Bila dilakukan dengan tepat, teknologi sterilisasi, apalagi dikombinasikan dengan penyimpanan suhu rendah sangat mendukung agroindustri modern yang sudah saatnya digalakkan untuk menggantikan pengolahan tradisional. Akan tetapi satu hal yang perlu mendapatkan perhatian dalam penerapan teknologi sterilisasi adalah kemungkinan kerusakan nutrisi karena aplikasi suhu tinggi yang berlebihan. Hasil-hasil penelitian telah membuktikan bahwa pemindangan ikan pada $100^{\circ} \mathrm{C}$ dengan garam $30 \%$ selama 15 menit telah menurunkan kandungan omega-3 hingga 14\% (Heruwati \& Murniyati, 1996); perebusan pada larutan garam jenuh selama 36 menit dapat mengurangi kadar lisin tersedia (available lysine) hingga 41,56\% (Basmal et al., 1997); dan pemanasan ikan pada $121^{\circ} \mathrm{C}$ selama 60 menit dapat menguraikan semua tiamin pirofosfat, yang jumlahnya sekitar $80 \%$ dari seluruh tiamin yang terdapat pada ikan (Suparno, 1996).

Salah satu keuntungan yang diperoleh dari teknologi sterilisasi adalah terjadinya penekanan jumlah bakteri dari $10^{6}$ hingga $10^{2}$ per gram, dan hanya bakteri gram positif yang dapat bertahan, sehingga kecil adanya peluang masih tersisanya bakteri penyebab penyakit dan keracunan, yang termasuk dalam kelompok gram negatif. Masih adanya bakteri gram positif yang kemungkinan disebabkan sterilisasi yang kurang sempurna atau kemasan yang tidak hermetis, menunjukkan bahwa keracunan botulisme masih mungkin terjadi. Untuk itu penyimpanan pada suhu rendah dapat membantu menghambat pertumbuhan bakteri C. botulinum. Keuntungan lain adalah karena teknologi ini mampu memberikan daya awet yang sama walaupun tanpa penyimpanan suhu rendah, sehingga dapat digunakan untuk produk pindang yang harus diangkut dari tempat yang jauh (hingga dua minggu perjalanan) meng. gunakan kapal laut, yang pada umumnya tidak dilengkapi dengan ruang pendingin. Produk harus diolah kembali untuk menjamin bebas botulisme.

\section{KESIMPULAN DAN SARAN}

Teknologi sterilisasi untuk ikan bandeng presto layak dilakukan untuk memperpanjang masa simpan produk karena dengan sterilisasi pada $118^{\circ} \mathrm{C}$ selama 15 menit, produk dapat disimpan selama empat minggu pada suhu kamar, dan mampu menekan jumlah bakteri, khususnya gram negatif, sehingga jumlah bakteri pada produk yang semula $10^{6}$ menjadi $10^{2}$ per gram, walaupun kemungkinan keracunan oleh bakteri gram positif (khususnya C. botulinum) tetap harus diwaspadai. Namun demikian, penelitian

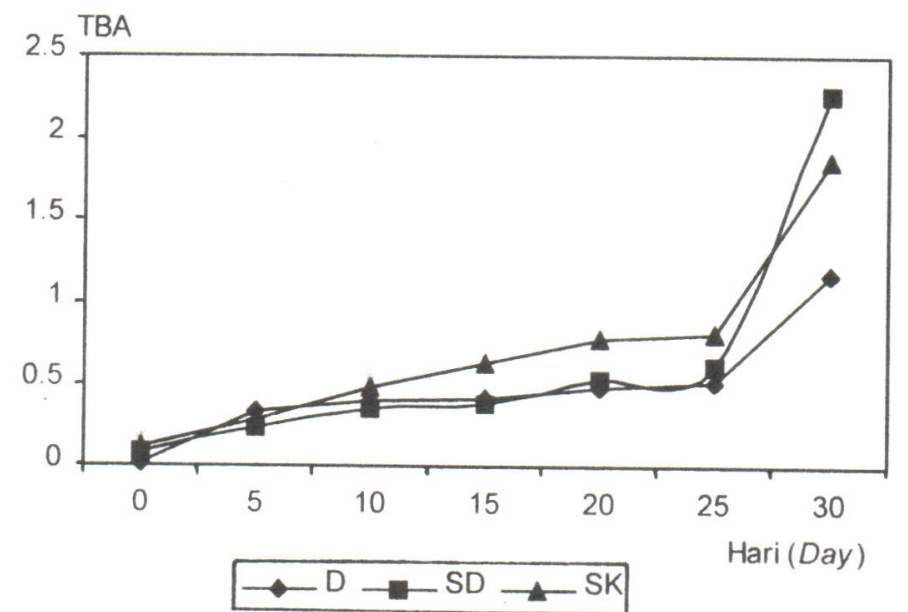

D: Tanpa sterilisasi, penyimpanan suhu rendah (unsterilized, low temperature storage)

SD: Dengan sterilisasi, penyimpanan suhu rendah (sterilized, low temperature storage)

SK: Dengan sterilisasi, penyimpanan suhu kamar (sterilized, room temperature storage)

Gambar 5. TBA (\% malonaldehide/kg) pindang presto selama penyimpanan.

Figure 5. TBA (um MA/kg) of pressure-cooked pindang during storage. 
perlu dilanjutkan untuk memperoleh suhu dan waktu sterilisasi yang tepat serta jenis kantong plastik yang lebih sesuai untuk keperluan tersebut.

\section{DAFTAR PUSTAKA}

Basmal, J., B.S.B. Utomo, dan K.D.A. Taylor. 1997. Pengaruh perebusan, penggaraman, dan penyimpanan terhadap penurunan kandungan lisin yang terdapat pada ikan pindang. J. Penelitian Perikanan Indonesia III(2):54-62.

Heruwati, E.S. 1985. Prospek dan masalah yang dihadapi dalam pengembangan ikan pindang di Indonesia. Jurnal Penelitian dan Pengembangan Pertanian. IV(4):103-107.

Heruwati, E.S. dan Murniyati. 1996. Pengaruh pemindangan dan pengemasan hampa udara terhadap kadar asam lemak omega-3 ikan pindang. J. Penelitian Perikanan Indonesia II(4):59-65.

Muljanah, I., H.E. Irianto, S. Nasran, dan A. Poernomo. 1986. Studi berbagai cara pengolahan pindang cue dalam rangka standarisasi. J. Penelitian Pascapanen Perikanan 56:25-33.

Noor, M., S. Saleh, Hanafi, dan Mahyudin. 1994. Penelitian penggunaan plastik tahan panas pengganti kaleng: 3 . Uji konsumen di Dati II Kab.
Bandung, Cirebon, dan DKI Jakarta. J. Penelitian Pascapanen Perikanan 80:45-63.

Saleh, M., M. Tampubolon, I. Muljanah, Suparno, dan M.D. Erlina. 1992. Penelitian penggunaan plastik tahan panas pengganti kaleng: 1. Percobaan pendahuluan pengolahan ikan lemuru ( $S$. longiceps) dalam kantong plastik hampa udara. J. Penelitian Pascapanen Perikanan 74:9-16.

Saleh, M., I. Muljanah, Murdinah, Tazwir, dan U. Rahayu. 1993. Penelitian penggunaan plastik tahan panas pengganti kaleng: 2. Daya awet ikan lemuru (S. longiceps) dalam kantong plastik hampa udara dengan media yang berbeda. J. Penelitian Pascapanen Perikanan 75:1-10.

Suparno. 1990. Storage of 'pindang' in vacuum and carbon dioxide atmosphere packages. Penelitian penggunaan plastik tahan panas pengganti kaleng: J. Penelitian Pascapanen Perikanan 63:21-32.

Suparno dan J.T. Murtini. 1981. Studi mengenai proses pemindangan : daya awet dan mutu pindang air garam selama penyimpanan. Bull. Penelitian Perikanan VI(2):219-226.

Suparno, S.W. Hanson, and A.J. Rosenthal. 1996. Thiamine in fish and its degradation during thermal processing of salted boiled fish. Indonesian Fisheries Research J. II(1):50-56. 